\title{
PENGARUH RASIO KEUANGAN TERHADAP KONDISI FINANCIAL DISTRESS PADA PERUSAHAAN MANUFAKTUR SUB SEKTOR KIMIA YANG TERDAFTAR DI BURSA EFEK INDONESIA TAHUN 2014-2017
}

\author{
*Amirah Hibatul Wafi, Arief Rahman, Nur Lailiyatul Inayah \\ Program Studi Akuntansi Fakultas Ekonomi dan Bisnis \\ Universitas Bhayangkara Surabaya, Indonesia
}

DOI: $10.46821 /$ equity.v1i1.7

\begin{abstract}
ABSTRAK
Penelitian ini bertujuan untuk mengetahui apakah rasio keuangan mempunyai pengaruh terhadap kondisi financial distress pada perusahaan manufaktur sub sektor kimia yang terdaftar di Bursa Efek Indonesia (BEI) periode 2014-2017. Untuk menentukan sampel dalam penelitian ini digunakan teknik non probability sampling, yaitu sampling purposive dengan menetapkan beberapa kriteria yang harus dipenuhi untuk digunakan sebagai sampel. Metode analisis yang digunakan adalah analisis regresi linear berganda dengan menggunakan bantuan SPSS Versi 25. Hasil penelitian menunjukkan bahwa hanya ada dua rasio keuangan yang berpengaruh signifikan terhadap financial distress, yaitu rasio working capital to total assets dan earning before interest and taxes to total assets. Sementara ke empat rasio lainnya tidak berpengaruh secara signifikan terhadap financial distress.
\end{abstract}

Kata Kunci: Financial Distress, Rasio Keuangan, Model Altman, Arus Kas

\begin{abstract}
This research aims to determine the effect of financial ratios to financial distress at a manufacturing company (chemical-sub) listed on Indonesia Stock Exchange (IDX) in period 2014-2017. To determine the sample in this research is using a non probability sampling technique (sampling purposive), by setting several criteria that must be met to be used as sample. The analytical method used in this research is multiple linear regression analysis with SPSS Version 25. The results of the research show that there are only two financial ratios that have a significant effect on financial distress. The ratios is working capital to total assets ratio and earning before interest and taxes ratio. While the other four ratios have no significant effect on financial distress.
\end{abstract}

Keywords: Financial Distress, Financial Ratios, Altman Ratios, Cash Flow

*Corresponding Author:

Email: amirahwafi54@gmail.com 


\section{PENDAHULUAN}

Vol. 1 No. 12020

Financial distress adalah kondisi dimana perusahaan meengalami kesulitan keuangan yang menyebabkan perusahaan tidak mampu untuk memenuhi kewajiban- kewajibannya pada saat jatuh tempo. Salah satu ciri perusahaan yang dikatakan mengalami financial distress adalah perusahaan yang mengalami kerugian selama tiga tahun berturut-turur atau perusahaan yang memiliki nilai earning per share (EPS) negatif. Perusahaan yang tidak dapat mengatasi kondisi financial distress dengan baik dapat berakhir dengan kebangkrutan. Oleh karena itu sangat penting bagi perusahaan untuk melakukan prediksi financial distress.

Salah satu cara yang dapat dilakukan untuk memprediksi kondisi financial distress adalah dengan melakukan analisis rasio keuangan. Pada penelitian kali ini, peneliti menggunakan rasio model Altman yang terdiri dari lima rasio yaitu, rasio working capital to total assets, retained earning to total asset, earning before interest and taxes to total assets, market value of equity to book value of total liabilities dan sales to total assets serta ditambah dengan rasio arus kas yaitu, rasio cash flow from operating to total assets. Pemilihan ke enam rasio ini dianggap sudah dapat mewakili jenis-jenis rasio yang ada.

\section{LANDASAN TEORI}

\section{Laporan Keuangan}

Laporan keuangan adalah laporan yang menunjukkan kondisi laporan keuangan saat ini atau dalam suatu periode tertentu (Kasmir, 2016:7). Laporan keuangan bertujuan untuk memberikan informasi mengenai posisi keuangan, kinerja keuangan dan arus kas entitas yang bermanfaat bagi perusahaan dan pihak-pihak berkepentingan lainnya (PSAK, Nomor 1 Revisi 2015).

\section{Analisis Rasio Keuangan}

Analisis rasio keuangan merupakan analisis yang dilakukan dengan menghubungkan berbagai perkiraan yang ada pada laporan keuangan dalam bentuk rasio keuangan (Hery, 2016:139). Ada beberapa jenis rasio keuangan, diantaranya adalah sebagai berikut:

1. Rasio Likuiditas

2. Rasio Profitabilitas

3. Rasio Financial Leverage

4. Rasio Pertumbuhan Penjualan

5. Rasio Aktivitas

6. Arus Kas

\section{Financial Distress}

Financial distress adalah kondisi dimana perusahaan meengalami kesulitan keuangan yang menyebabkan perusahaan tidak mampu untuk memenuhi kewajiban- kewajibannya pada saat jatuh tempo. Menurut Rudianto (2013:253) informasi prediksi financial distress bermanfaat untuk membantu manajemen 
dalam melakukan perbaikan- perbaikan dan pencegahan agar terhindar dari kondisi financial distress. Selain itu bermanfaat untuk memberikan gambaran mengenai kemampuan perusahaan dalam mengelola investasi yang ditanamkan oleh pihak eksternal.

\section{Faktor-Faktor Penyebab Terjadinya Financial Distress}

Menurut Demodaran, faktor-faktor penyebab terjadinya financial distress dapat dibedakan menjadi dua, yaitu faktor internal dan faktor eksternal. Faktor internal berupa kesulitan arus kas dan besarnya jumlah hutang yang dimiliki perusahaan. Sedangkan faktor eksternal dapat disebabkan oleh kebijakan pemerintah yang dapat menambah beban usaha yang ditanggung oleh perusahaan, seperti kenaikan tarif pajak dan kenaikan suku bunga pinjaman.

\section{HIPOTESIS}

H1: Working Capital to Total Asset (WCTA) berpengaruh signifikan terhadap kondisi financial distress perusahaan.

H2: Retained Earnings to Total Asset (RETA) berpengaruh signifikan terhadap kondisi financial distress perusahaan.

H3: Earning Before Interest and Tax to Total Asset (EBITTA) berpengaruh signifikan terhadap kondisi financial distress perusahaan.

\section{METODE PENELITIAN}

\section{Variabel Dependen}

Variabel dependen dalam penelitian ini adalah financial distress. Perusahaan dikatakan mengalami financial distress apabila memiliki nilai EPS negatif. Oleh karena itu untuk mengukur nilai variabel dependen ini menggunakan variabel dummy, yaitu dengan melihat nilai EPS perusahaan. Variabel dummy bernilai 1 apabila perusahaan mengalami nilai EPS negatif dan bernilai 0 apabila nilai EPS perusahaan positif.

\section{Variabel Independen}

Variabel independen dalam penelitian ini menggunakan rasio model Altman serta ditambah dengan rasio arus kas.

1. Rasio Working Capital to Total Assets (WCTA), menunjukkan kemampuan perusahaan dalam menghasilkan modal kerja bersih dari total aset yang dimilikinya.

$$
\text { WCTA }=\frac{\text { Working Capital }}{\text { Total Assets }}
$$

2. Rasio Retained Earning to Total Assets (RETA), menunjukkan kemampuan perusahaan dalam menghasilkan laba, sebagai laba ditahan setelah dikurangi beban-beban. 
RETA $=\underline{\text { Retained Earning }}$

Total Assets

3. Rasio Earning Before Interest and Taxes to Total Assets (EBITTA), mengukur kemampuan perusahaan untuk menghasilkan laba dari aset yang digunakannya.

EBITTA $=\underline{\text { Earning Before Interest and Taxes }}$

Total Assets

4. Rasio Market Value of Equity to Book Value of Total Liabilities (MVTL), menunjukkan kemampuan perusahaan untuk memenuhi kewajibannya dari nilai pasar modal sendiri.

MVTL $=\frac{\text { Market Value of Equity }}{\text { Total Liabilities }}$

5. Rasio Sales to Total Assets (SETA), menunjukkan kemampuan perusahaan dalam menghasilkan penjualan dari aset yang dimilikinya.

SETA $=\frac{\text { Sales }}{\text { Total Assets }}$

6. Rasio Cash Flow from Operating to Total Assets (CFOTA), menunjukkan kemampuan perusahaan dalam menghasilkan aliran kasnya melalui aset yang dilikinya.

CFOTA $=$ Cash Flow from Operating

Total Assets

\section{Jenis dan Sumber Data}

Jenis data yang digunakan dalam penelitian ini adalah data sekunder yang dilaporkan oleh perusahaan yang terdaftar di Bursa Efek Indonesia. Sedangkan sumber data yang digunakan dalam penelitian ini adalah data yang berasal dari laporan keuangan masing-masing perusahaan sampel selama masa penelitian yaitu dari tahun 2014-2017.

\section{Populasi dan Sampel}

Populasi dalam penelitian ini adalah seluru perusahaan manufaktur sub sektor kima yang terdaftar di BEI dari tahun 2014-2017 dengan jumlah populasi sebanyak 13 perusahaan. Sedangkan pemilihan sampel dalam penelitian ini dilakukan dengan teknik purposive sampling yang didasarkan pada beberapa kriteria tertentu sehingga diperoleh 9 perusahaan yang memenuhi kriteria untuk dijadikan sampel.

\section{Alat Analisis Data}

Alat yang digunakan dalam penelitian ini adalah program SPSS versi 25 dengan uji statistik sebagai berikut: 
1. Analisis regresi linear berganda dengan uji asumsi klasik:

a. Uji Normalitas

b. Uji Heteroskedastisitas

c. Uji Autokorelasi

d. Uji Multikolinearitas

2. Uji T (Parsial)

3. Uji F (Simultan)

\section{HASIL DAN PEMBAHASAN}

\section{Hasil Uji Normalitas}

Uji normalitas bertujuan untuk menguji apakah model regresi yang digunakan berdistribusi normal. Dasar pengambilan keputusan dalam uji ini adalah apabila nilai asymp. sig. (2-tailed) >0,05 maka data berdistribusi normal. Berdasarkan Tabel 1, diketahui nilai asymp. sig. (2-tailed) sebesar $(0,200>0,05)$ maka dapat disimpulkan bahwa data berdistribusi normal.

\section{Hasil Uji Heteroskedastisitas}

Berdasarkan Gambar 1, diketahui bahwa titik-titik tidak membentuk pola yang jelas serta menyebar di atas dan di bawah angka 0 apada sumbu Y. Maka dapat disimpulkan bahwa tidak terjadi heteroskedastisitas dalam model regresi.

Tabel 1. Hasil Uji Normalitas

\begin{tabular}{lrr}
\hline & & One-Sample Kolmogorov-Smirnov Test \\
\hline $\mathrm{N}$ & & Unstandardized Residual \\
Normal & Mean & 36 \\
Parameters & Std. Deviation &, 0000000 \\
Asymp. Sig. (2-tailed) &, 25125300 \\
Test distribution is Normal. &, $200^{\text {c,d }}$ \\
\hline
\end{tabular}

Sumber: Hasil Olahan Peneliti (2019)

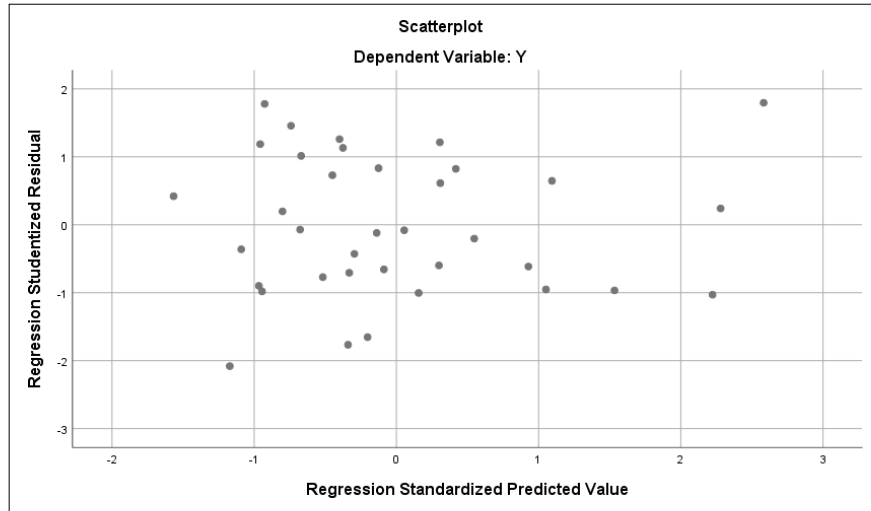

Sumber: Hasil Olahan Peneliti (2019)

Gambar 1. Hasil Uji Heteroskedastisitas 


\section{Hasil Uji Autokorelasi}

Vol. 1 No. 12020

Berdasarkan hasil uji Run Test dapat diketahui bahwa nilai asymp. sig. (2-tailed) sebesar $(0,063>0,05)$ maka dapat disimpulkan bahwa tidak terjadi gejala autokorelasi pada model regresi (Tabel 2).

\section{Hasil Uji Multikolinearitas}

Dasar pengambilan keputusan dalam uji ini adalah apabila nilai tolerance $>0,10$ dan nilai $\mathrm{VIF}<10,00$ maka tidak terjadi multikolinearitas.

Berdasarkan Tabel 3, diketahui bahwa ke enam variabel memiliki nilai tolerance $>0,10$ sedangkan nilai VIF dari ke enam variabel $<10,00$ maka dapat disimpulkan bahwa tidak terjadi gejala multikolinearitas dalam model regresi.

\section{Uji T (Parsial)}

Uji T bertujuan untuk mengetahui adanya pengaruh yang signifikan atau tidak dari masing-masing variabel independen terhadap variabel dependen (Tabel 4).

Tabel 2. Uji Run Test

\begin{tabular}{lr}
\hline & Unstandardized Residual \\
\hline Test Value $^{\mathrm{a}}$ &,- 00050 \\
Cases $<$ Test Value & 18 \\
Cases $>=$ Test Value & 18 \\
Total Cases & 36 \\
Number of Runs & 13 \\
$Z$ & $-1,860$ \\
Asymp. Sig. (2-tailed) &, 063 \\
\hline Sumber: Hasil Olahan Peneliti (2019)
\end{tabular}

Tabel 3. Uji Multikolinearitas

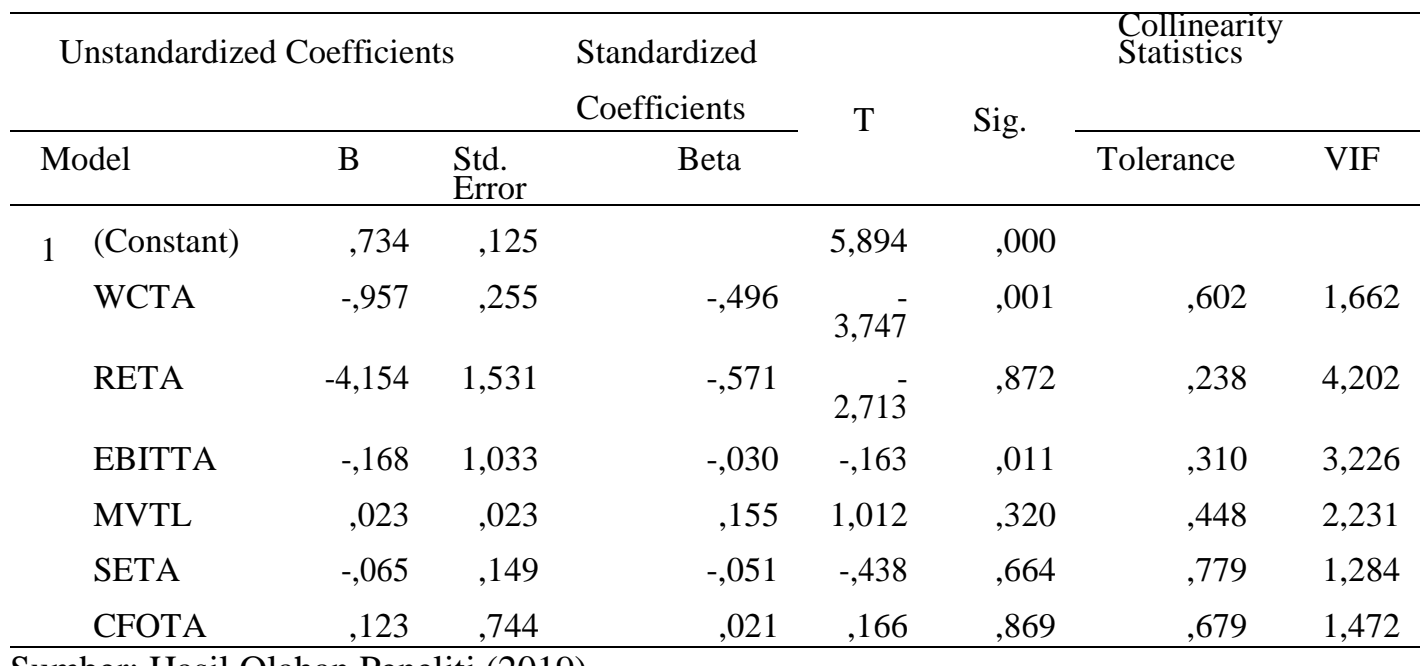

Sumber: Hasil Olahan Peneliti (2019) 
Tabel 4. Uji T

\begin{tabular}{|c|c|c|c|c|c|c|c|c|}
\hline \multicolumn{4}{|c|}{ Unstandardized Coefficients } & \multirow{2}{*}{$\begin{array}{c}\begin{array}{c}\text { Standardize } \\
\text { Coefficients }\end{array} \\
\text { Beta }\end{array}$} & \multirow[b]{2}{*}{$\mathrm{T}$} & \multirow[b]{2}{*}{ Sig. } & \multicolumn{2}{|c|}{$\begin{array}{l}\text { Collinearity } \\
\text { Statistics }\end{array}$} \\
\hline & del & $\mathrm{B}$ & $\begin{array}{l}\text { Std. } \\
\text { Error }\end{array}$ & & & & Tolerance & VIF \\
\hline \multirow[t]{7}{*}{1} & (Constant) & ,734 &, 125 & & 5,894 & ,000 & & \\
\hline & WCTA &,- 957 &, 255 &,- 496 & $-3,747$ &, 001 & ,602 & 1,662 \\
\hline & RETA & $-4,154$ & 1,531 &,- 571 & $-2,713$ & ,872 & 238 & 4,202 \\
\hline & EBITTA &,- 168 & 1,033 &,- 030 &,- 163 & 011 & ,310 & 3,226 \\
\hline & MVTL &, 023 & 023 &, 155 & 1,012 &, 320 & ,448 & 2,231 \\
\hline & SETA &,- 065 & 149 &,- 051 &,- 438 & ,664 & ,779 & 1,284 \\
\hline & CFOTA &, 123 & ,744 & ,021 &, 166 & ,869 & 679 & 1,472 \\
\hline
\end{tabular}

Sumber: Hasil Olahan Peneliti (2019)

Tabel 5. Uji F

\begin{tabular}{|c|c|c|c|c|c|c|}
\hline \multicolumn{2}{|c|}{ Model } & $\begin{array}{l}\text { Sum of } \\
\text { Squares }\end{array}$ & Df & $\begin{array}{l}\text { Mean } \\
\text { Square }\end{array}$ & $\mathrm{F}$ & Sig. \\
\hline \multirow[t]{3}{*}{1} & Regression & 5,013 & 6 &, 835 & 10,966 &, $000^{b}$ \\
\hline & Residual & 2,209 & 29 & ,076 & & \\
\hline & Total & 7,222 & 35 & & & \\
\hline
\end{tabular}

Sumber: Hasil Olahan Peneliti (2019)

Dasar pengambilan keputusan dalam uji ini adalah apabila $t$ hitung $<\mathrm{t}$ tabel dengan nilai signifikansi lebih kecil dari 0,05 maka artinya terdapat pengaruh yang signifikan terhadap financial distress.

Berdasarkan hasil Tabel 4, diketahui bahwa hanya ada dua rasio yang berpengaruh terhadap financial distress, yaitu rasio WCTA dengan $t$ hitung sebesar -3,747 < t tabel 2,045 dan nilai signifikansi sebesar 0,001 $<0,05$, dan rasio EBITTA dengan $\mathrm{t}$ hitung sebesar $-0,163<\mathrm{t}$ tabel 2,045 dan nilai signifikansi sebesar 0,011 < 0,05. Sedangkan ke empat rasio lainnya, yaitu rasio RETA, MVTL, SETA dan CFOTA memiliki nilai signifikansi lebih besar dari 0,05 yang artinya ke empat rasio tersebut tidak berpengaruh signifikan terhadap financial distress.

\section{Uji F (Simultan)}

Berdasarkan Tabel 5, diketahui bahwa nila F hitung sebesar 10,966 lebih besar dari $\mathrm{F}$ tabel 2,42 dengan nilai signifikansi 0,000 maka dapat disimpulkan bahwa rasio WCTA, RETA, EBITTA, MVTL, SETA dan CFOTA secara simultan berpengaruh signifikan terhadap financial distress.

\section{SIMPULAN}

Berdasarkan penelitian yang telah dilakukan dengan melalui beberapa uji yang telah dijelaskan sebelumnya, maka dapat disimpulkan dari ke enam rasio yang digunakan, yaitu rasio WCTA, RETA, EBITTA, MVTL, SETA dan CFOTA hanya ada dua rasio yang berpengaruh terhadap financial distress, yaitu rasio 
WCTA dengan $t$ hitung sebesar $-3,747<\mathrm{t}$ tabel 2,045 dan nilai signifikansi sebesar 0,001 $<0,05$, dan rasio EBITTA dengan t hitung sebesar $-0,163<\mathrm{t}$ tabel 2,045 dan nilai signifikansi sebesar 0,011<0,05. Sedangkan ke empat rasio lainnya, yaitu rasio RETA, MVTL, SETA dan CFOTA memiliki nilai signifikansi lebih besar dari 0,05 yang artinya ke empat rasio tersebut tidak berpengaruh signifikan terhadap financial distress. Penelitian ini hanya menggunakan empat tahun periode pengamatan tanpa menguji satu atau dua tahun periode prediksi sebelum terjadi financial distress dengan menggunakan rasio model Altman dan arus kas. Oleh karena itu diharapkan untuk peneliti selanjutnya dapat melakukan periode prediksi lebih dari tiga tahun sebelum terjadi financial distress sehingga dapat menghasilkan hasil prediksi yang lebih baik. Selain itu peneliti selanjutnya juga dapat menambahkan rasio-rasio lain yang mungkin lebih berpengaruh terhadap terjadinya kondisi financial distress.

\section{DAFTAR PUSTAKA}

Driati, Minda, 2014, Pengaruh Rasio Keuangan Dengan Model Altman dan Arus Kas Operasi Terhadap Prediksi Kondisi Financial Distress Perusahaan (Studi Pada Perusahaan Group Bakrie yang Terdaftar Di Bursa Efek Indonesia Dari Tahun 2005-2012), Program Studi Akuntansi Fakultas Ekonomi, Universitas Komputer Indonesia.

Hery. 2016 Analisis Laporan Keuangan. Jakarta: PT Gramedia Widiasarana Indonesia. Ikatan Akuntansi Indonesia. PSAK No. 1 Tentang Laporan Keuangan - Edisi Revisi 2015. Penerbit Dewan Standar Akuntansi Keuangan: PT. Raja Grafindo.

Oktarina, Eka, 2017, Analisis Prediksi Kebangkrutan Dengan Metode Altman Z- Score Pada PT. BRI Syariah, Fakultas Ekonomi dan Bisnis Islam, Universitas Islam Negeri Raden Fatah.

Rahmawati, Aryani Intan Endah dan P. Basuki Hadiprajitno, 2015, Analisis Rasio Keuangan Terhadap Kondisi Financial Distress Pada Perusahaan Manufaktur Yang Terdaftar di Bursa Efek Indonesia Tahun 2008-2013, Diponegoro Journal of Accounting. Jurusan Akuntansi Fakultas Ekonomika dan Bisnis, Universitas Diponegoro, Volume 4, Nomor 2, Halaman 1-11.

Rudianto, 2013, Akuntansi Manajemen Informasi Untuk Pengambilan Keputusan Strategis, Jakarta: Erlangga

Sugiyono, 2016, Metode Penelitian kuantitatif, Kualitatif dan R\&D, Cetakan Ke23, Bandung: Alfabeta.

Theresia Natalia Sabu Suma Tukan, 2018, Analisis Faktor Penjelas Financial

Distress Pada Perusahaan Manufaktur di Bursa Efek Indonesia, Fakultas Ekonomi, Universitas Negeri Yogyakarta. 